\title{
Isolation of dihydroxyacetone-producing acetic acid bacteria in Vietnam
}

- Vu Thi Lan Huong

- Nguyen Thi Kim Oanh

- Bui Thi Thu Van

- Bui Thi Tu Uyen

- Ngo Dai Nghiep

- Dang Thi Phuong Thao

University of Science, VNU-HCM

- Pattaraporn Yukphan

National Center for Genetic Engineering and Biotechnology (BIOTEC), NSTDA, Thailand

(Received on $1^{\text {st }}$ December 2015, accepted on $2^{\text {nd }}$ December 2016)

\begin{abstract}
Sixty-six acetic acid bacteria $(A A B)$ were isolated from fourty-five flowers and fruits collected in Hochiminh City, Vietnam. Of the sixty-six, thirty-one isolates were selected as dihydroxyacetone (DHA)-producing $A A B$ based on the reaction with Fehling's solution and grouped into three groups by routine identification with phenotypic features. Group I composed of fourteen isolates and was assigned to the genus Acetobacter, Group II composed of thirteen isolates and was assigned to the genus

Gluconobacter and Group III was the remaining
\end{abstract} four isolates and was assigned to the genus Gluconacetobacter. Ten isolates among the thirteen isolates of Group II gave a larger amount of DHA (22.2-26.0 $\mathrm{mg} / \mathrm{mL})$ than Gluconobacter oxydans NBRC $14819^{T} \quad(19.8$ $m g / m L)$, promising for the potential use in producing DHA. In phylogenetic analysis based on 16S rRNA gene sequences, six isolates of the ten potential DHA producers were suggested to be candidates for new taxa in the genus Gluconobacter.

Key words: acetic acid bacteria, dihydroxyacetone-producing, Gluconobacter

\section{INTRODUCTION}

The production of dihydroxyacetone (DHA) is of interest in various applications in cosmetic, medicine, pharmaceuticals and food industries and in very cheap cost of glycerol, as the substrate for DHA production, due to the overproduction of this material by the biodiesel industry [10]. In acetic acid bacteria, strains assigned to Gluconobacter oxydans are widely used in the production of DHA through a microbiological method $[6,8]$. Except for strains of the genus Gluconobacter, strains of some other genera of acetic acid bacteria such as the genera Acetobacter, Gluconacetobacter, Asaia, Kozakia, Swaminathania, Neoasaia, Tanticharoenia, Ameyamaea, Komagataeibacter and Endobacter were also reported to have the ability to produce DHA [8]. Acetic acid bacteria showed an abundant diversity in tropical countries such as Thailand, Indonesia and the Philipines. Vietnam is also a tropical country, however, there is no research on the microbial DHA producing in Vietnam. Futhermore, it is quite rare report about the diversity of acetic acid bacteria in Vietnam. 
This study aims to preliminarily investigate the richness of diversity and the industrial applicability of bacterial resources in Vietnam through the isolation of DHA-producing $\mathrm{AAB}$ from fruits and flowers based on physiological and biochemical characterization and on the $16 \mathrm{~S}$ rRNA gene sequence along with screening for the DHA forming ability.

\section{MATERIALS AND METHODS}

\section{Isolation of $\mathrm{AAB}$}

$\mathrm{AAB}$ were isolated from 29 fruit and 16 flower samples collected in Hochiminh City, Vietnam by an enrichment culture approach using pH 3.5 medium [20]. After two days of incubation, a culture showing microbial growth was streaked onto a GEY-agar plate containing $0.3 \% \mathrm{CaCO}_{3}(\mathrm{w} / \mathrm{v})$. The acid-producing bacterial strains that formed a clear zone around the colony on the agar plate were selected for testing the growth at $\mathrm{pH}$ 3.5. Isolated strains were examined for their Gram stain, cell shape and catalase/oxidase formation by conventional methods.

Screening of strains producing DHA from glycerol

The isolates selected as AAB were qualitatively analyzed for the ability to produce DHA. Bacterial cells were incubated in a DHA production medium containing $3.0 \%$ glycerol, $0.5 \%$ yeast extract, $1.0 \%$ peptone (all by w/v) under a shaking condition for seven days at $30^{\circ} \mathrm{C}$ and $\mathrm{pH}$ 6.0. A DHA-producing ability was detected by the appearance of the orange color in a bacterial supernatant with Fehling's solution [1].

For the quantitative analysis of DHA, potentially selected isolates and the reference strain were cultivated in the DHA production medium for $24 \mathrm{~h}$. One $\mathrm{mL}$ of each culture $(0.5$ optical density at $600 \mathrm{~nm}$ ) was transferred to a $200 \mathrm{~mL}$ beaker containing the same medium and incubated at $30{ }^{\circ} \mathrm{C}$ on a rotary shaker $(150 \mathrm{rpm})$ for $48 \mathrm{~h}$. The supernatant of the cultivated broth was investigated for the amounts of DHA produced by the DNS (3,5-dinitrosalicylic acid) method according to Burner (1964) [3]. Pure dihydroxyacetone was used as standardizer. All the chemical agents was purchased from either Merck (Germany) or Sigma (USA).

The most potent and widely studied bacterium for DHA production is the species Gluconobacter oxydans [2, 3, 6, 10, 13]. The type strain Gluconobacter oxydans NBRC $14819^{\mathrm{T}}$ was used as a DHA-producing reference strain.

Routine identification of DHA-producing $\mathrm{AAB}$

Physiological and biochemical characterizations including the oxidation of acetate and lactate, the production of acetic acid from ethanol and of water-soluble brown pigments, the growth in the presence of $0.35 \%$ acetic acid (v/v), on $30 \%$ D-glucose (w/v) and on glutamate agar were made, as previously reported [1, 19, 20, 22, 23]. Gluconobacter oxydans NBRC $14819^{\mathrm{T}}$, Acetobacter aceti NBRC $14818^{\mathrm{T}}$, Gluconacetobacter liquefaciens NBRC $12388^{\mathrm{T}}$, Asaia bogorensis NBRC $16594^{\mathrm{T}}$, Kozakia baliensis NBRC $16664^{\mathrm{T}}$ were used as reference strains.

Phylogenetic analysis of 16S rRNA genes for highly DHA-producing AAB

PCR amplification of 16S rRNA genes was carried out, and amplified 16S rRNA genes were sequenced and analyzed, as described previously [12, 15, 17, 18]. Multiple sequence alignments were done with the program CLUSTAL $X$ (version 1.8) [17]. Alignment gaps and unidentified bases were eliminated. Genetic distances for the aligned sequences were calculated using the two-parameter method of Kimura (1960) [7]. A phylogenetic tree based on $16 \mathrm{~S}$ rRNA gene sequences of 1,382 bases derived from the neighbor joining method was constructed by the use of the program MEGA 5 (version 5.05) [14, 16]. The robustness for

Trang 32 
individual branches was estimated by bootstrapping with 1,000 replications [5].

\section{RESULTS AND DISCUSSION}

\section{Isolation AAB}

Sixty-six isolates were selected as AAB from 45 samples (Table 1). They formed clear zones of $\mathrm{CaCO}_{3}$ on GEY-agar. Most of isolates gave creamy, brownish or pale yellow when colonies were grown on GECA. There were no isolates with a pink colony. They grew at $\mathrm{pH} 3.5$ and showed positive catalase and negative oxidase. They were Gram-negative and rod shaped. There were 21 isolates from 16 flower samples and 45 isolates from 29 fruit samples. Kommanee et al. (2012) obtained 24 isolates from 22 fruits and 2 flowers samples collected in Thailand. Meanwhile, Moryadee and Pathum-Aree (2008) obtained 60 thermotolorant AAB from 13 kinds of fruits from Thai sources [8, 11]. Yamada et al. (1999) obtained 64 isolates in Indonesia, although they did not mention either the number of isolation sources or the kinds of isolation source [20]. Considering the numbers of 66 isolates obtained from 36 kinds of isolation sources, it can be preliminarily assumed that the presence of $\mathrm{AAB}$ in Vietnam is quite general (Table 1).

Table 1. Isolates and their isolation sources

\begin{tabular}{|c|c|c|c|c|}
\hline No. & Isolation source & $\begin{array}{c}\text { Type of } \\
\text { isolation } \\
\text { source } \\
\end{array}$ & $\begin{array}{c}\text { No. of } \\
\text { samples }\end{array}$ & Isolates \\
\hline 1 & Water convolvulus & Flower & 1 & VTH-AE01 \\
\hline 2 & Mango & Flower & 1 & VTH-AE02 \\
\hline 3 & Gandaria & Flower & 1 & VTH-AE12 \\
\hline 4 & Crêpe ginger & Flower & 2 & $\begin{array}{l}\text { VTH-AE18, VTH-AH38, VTH-AH41, } \\
\text { VTH-AH42, VTH-AH46 }\end{array}$ \\
\hline 5 & Yellow apricot & Flower & 1 & VTH-AE47 \\
\hline 6 & Jambu air & Flower & 1 & VTH-AE57 \\
\hline 7 & Crape jasmine & Flower & 1 & VTH-AE65, VTH-AE66 \\
\hline 8 & Frangipani & Flower & 1 & VTH-AE70, VTH-AH69 \\
\hline 9 & Blue pea & Flower & 1 & VTH-AE77 \\
\hline 10 & Giant spider lily & Flower & 1 & VTH-AH52 \\
\hline 11 & Ponna & Flower & 1 & VTH-AE83 \\
\hline 13 & Blue skyflower & Flower & 1 & VTH-AH71 \\
\hline 13 & Rose & Flower & 1 & VTH-AK36 \\
\hline 14 & Shoeblackplant & Flower & 1 & VTH-AK16 \\
\hline 15 & Tonkin jasmine & Flower & 1 & VTH-AK26 \\
\hline 16 & Orange. & Fruit & 2 & VTH-AE28, VTH-AE39, VTH-AK33 \\
\hline 17 & Strawberry & Fruit & 2 & VTH-AE44, VTH-AK14 \\
\hline 18 & Pineapple & Fruit & 1 & VTH-AE67, VTH-AE73, VTH-AE99 \\
\hline 19 & Jambu air & Fruit & 3 & $\begin{array}{l}\text { VTH-AE } 75, \text { VTH-AH } 49, \text { VTH-AK23, } \\
\text { VTH-AK30 }\end{array}$ \\
\hline 20 & Mandarin orange & Fruit & 1 & VTH-AE76, VTH-AH62 \\
\hline 21 & Avocado & Fruit & 1 & VTH-AE94 \\
\hline 22 & Grape & Fruit & 3 & $\begin{array}{l}\text { VTH-AH37, VTH-AH39, VTH-AH47, VTH- } \\
\text { AK04, VTH-AK20 }\end{array}$ \\
\hline 23 & Star fruit & Fruit & 1 & VTH-AH55, VTH-AH59 \\
\hline 24 & Mango & Fruit & 2 & $\begin{array}{l}\text { VTH-AH57, VTH-AK17, VTH-AK18, VTH- } \\
\text { AK19 }\end{array}$ \\
\hline 25 & Sapodilla & Fruit & 1 & VTH-AH61, VTH-AH72 \\
\hline 26 & Paradise apple & Fruit & 1 & VTH-AH81 \\
\hline 27 & Coconut & Fruit & 2 & VTH-AH82, VTH-AH89, VTH-AK15, VTH- \\
\hline
\end{tabular}




\begin{tabular}{|lllll|} 
& & & AK28 \\
28 & Gandaria & Fruit & 1 & VTH-AK05 \\
29 & Barbados cherry & Fruit & 1 & VTH-AK07 \\
30 & Buffalo thorn & Fruit & 1 & VTH-AK21, VTH-AK31 \\
31 & White mulberry & Fruit & 1 & VTH-AK12 \\
32 & Oleaster-leafed pear & Fruit & 1 & VTH-AK22 \\
33 & Sugar-apple & Fruit & 1 & VTH-AK24, VTH-AK25, VTH-AK37 \\
34 & Papaya & Fruit & 1 & VTH-AK29 \\
35 & Rambutan & Fruit & 1 & VTH-AK34 \\
36 & Water melon & Fruit & 1 & VTH-AK32 \\
\hline
\end{tabular}

Screening of DHA-producing AAB and routine identification of selected DHAproducing AAB

Sixty-six isolates of selected AAB were examined for the qualitative screening of DHAproducing ability by using the Fehling's solution. Of the sixty-six, thirty-one isolates showed orange precipitations in the Fehling's solution and were designated as DHA-producing AAB (Table 1)

The thirty-one DHA-producing $\mathrm{AAB}$ were grouped into three groups by the routine identification [21].

Group I showed that the oxidation of acetate and lactate was positive, the acetic acid production from ethanol was positive, the growth was positive in the presence of $0.35 \%$ acetic acid $(\mathrm{v} / \mathrm{v})$ but negative on glutamate agar and the production of water-soluble brown pigments was negative. Group I was assigned belonging to the genus Acetobacter and included fourteen isolates, comprised of VTH-AE39, VTH-AE76, VTHAE75, VTH-AH55, VTH-AK62, VTH-AK07, VTH-AK17, VTH-AK18, VTH-AK19, VTHAK22，VTH-AK26，VTH-AK28，VTH-AK29 and VTH-AK32.

Group II showed the that oxidation of acetate and lactate was negative, the acetic acid production from ethanol was positive, the growth was positive in the presence of $0.35 \%$ acetic acid $(\mathrm{v} / \mathrm{v})$ but negative on glutamate agar and the production of water-soluble brown pigments was positive or negative. It was assigned to the genus
Gluconobacter and included thirteen isolates, comprised of VTH-AE18, VTH-AE44, VTHAE57, VTH-AE67, VTH-AE83, VTH-AH39, VTH-AH46, VTH-AH59, VTH-AH69, VTHAH82, VTH-AK04, VTH-AK12 and VTHAK36.

Group III showed that the oxidation of acetate and lactate was positive but delayed, the acetic acid production from ethanol was positive, the growth was positive in the presence of $0.35 \%$ acetic acid (v/v) and on glutamate agar and the production of water-soluble brown pigments was positive. It was assigned to the genus Gluconacetobacter and included four isolates, comprised of VTH-AH38, VTH-AH41, VTHAH42 and VTH-AK05.

Production of DHA by the selected DHAproducing $\mathrm{AAB}$

The selected DHA-producing AAB were examined for the production of DHA. The amounts of DHA produced were from 0.17 to $25.98 \mathrm{mg} / \mathrm{mL}$ (Table 2). Instead, Gluconobacter oxydans NBRC $14819^{\mathrm{T}}$ produced $19.78 \mathrm{mg} / \mathrm{mL}$. Among thirty-one tested isolates, excellent DHA producers were restricted only to ten isolates assigned to the genus Gluconobacter, showing 22.20-25.98 $\mathrm{mg} / \mathrm{mL}$. When examined on Thai Gluconobacter isolate PHD-27 for duration of 96 hours, Kommanee et al. (2012) obtained an amount of approximately $21 \mathrm{~g} / \mathrm{L}$ (or $\mathrm{mg} / \mathrm{mL}$ ) DHA for 48 hours at $30{ }^{\circ} \mathrm{C}$. These data suggested that yield of DHA production of the ten Gluconobacter isolates from Vietnam was similar to that of the Thai isolate.

\section{Trang 34}


Table 2. Amounts of DHA produced by the selected DHA-producting AAB with their groups by routine identification

\begin{tabular}{|c|c|c|}
\hline $\begin{array}{l}\text { Group by routine } \\
\text { identification }\end{array}$ & $\begin{array}{l}\text { Isolates and their amount of DHA production } \\
\qquad(\mathrm{mg} / \mathrm{mL})\end{array}$ & Isolation sources \\
\hline $\begin{array}{l}\text { Group I } \\
\text { Identified as } \\
\text { Acetobacter }\end{array}$ & 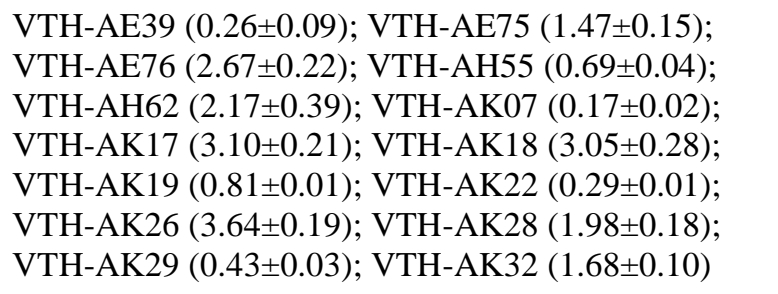 & $\begin{array}{l}\text { Flower of Tonkin jasmine } \\
\text { Fruit of Orange, Jambu air, } \\
\text { Mandarin orange, Star fruit, } \\
\text { Oleaster-leafed pear, Mango, } \\
\text { Barbados cherry, Coconut, } \\
\text { Papaya and Water melon }\end{array}$ \\
\hline $\begin{array}{l}\text { Group II } \\
\text { Identified as } \\
\text { Gluconobacter }\end{array}$ & 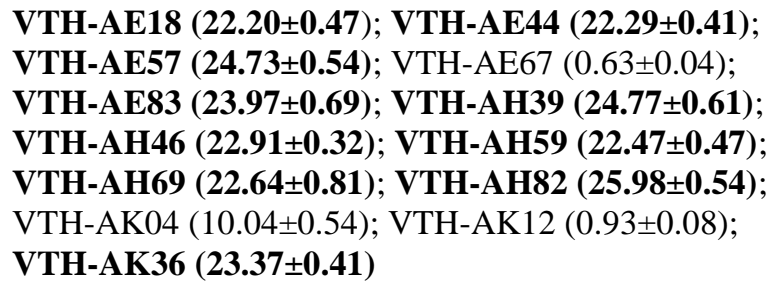 & $\begin{array}{l}\text { Flower of Crêpe ginger, Ponna, } \\
\text { Frangipani and Rose } \\
\text { Fruit of Strawberry, Mango, } \\
\text { Pineapple, Grape, Star fruit, } \\
\text { Coconut and White mulberry }\end{array}$ \\
\hline $\begin{array}{l}\text { Group III } \\
\text { Identified as } \\
\text { Gluconacetobacter }\end{array}$ & $\begin{array}{l}\text { VTH-AH38 }(6.42 \pm 0.71) \text {; VTH-AH41 }(5.91 \pm 0.34) ; \\
\text { VTH-AH42 (5.83 } \pm 0.36) ; \text { VTH-AK05 }(1.13 \pm 0.55)\end{array}$ & $\begin{array}{l}\text { Flower of Crêpe ginger } \\
\text { Fruit of Gandaria }\end{array}$ \\
\hline
\end{tabular}

Phylogenetic relationship of highly DHAproducing selected $A \mathrm{AB}$

The highly DHA-producing ten $\mathrm{AAB}$ were examined phylogenetically. As shown in Fig. 1, all the ten isolates were included in the lineage of the genus Gluconobacter. Firstly, the two isolates, VTH-AH69 and VTH-AK36 were phylogenetically related to either $G$. oxydans NBRC $14819^{\mathrm{T}}$ or G. roseus NBRC $3990^{\mathrm{T}}$. Secondly, the four isolates, VTH-AE44, VTHAE83, VTH-AH39 and VTH-AH59 that were related to G. uchimurae $\mathrm{ZW} 160-2^{\mathrm{T}}$ appeared to constitute a separate and independent taxon. Thirdly, the two isolates, VTH-AE18 and VTHAH82 respectively formed independent clusters and obviously constituted separate taxa. Fourthly, the two isolates, VTH-AE57 and VTH-AH46 were related to G. japonicus NBRC $3271^{\mathrm{T}}$. The obtained phylogenetic results suggested that six isolates of the ten are candidates for three new taxa. 


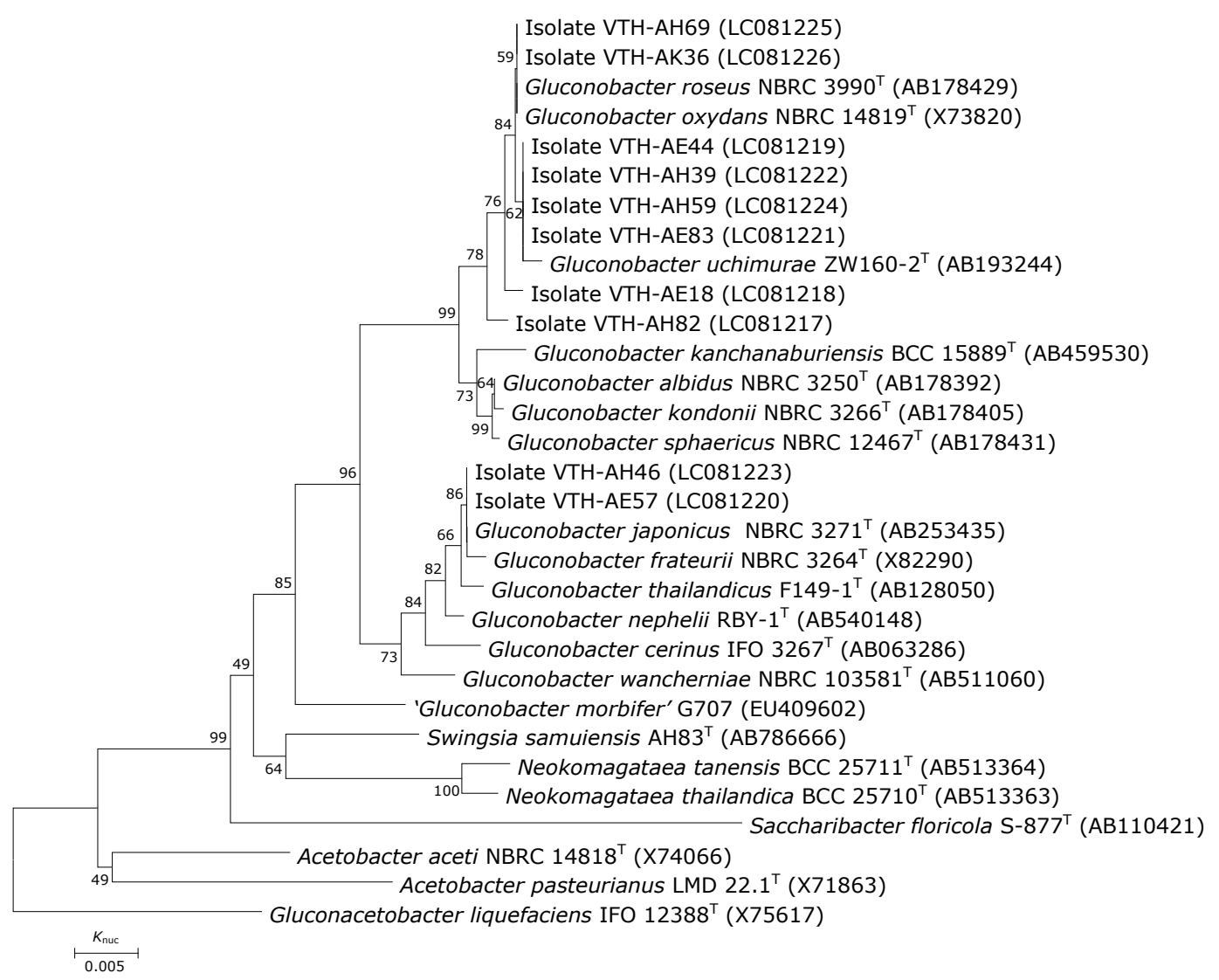

Figure 1. Phylogenetic relationships of the ten Gluconobacter isolates (with the species in the genus Gluconobacter). The phylogenetic tree based on 16S rRNA gene sequences was constructed by the neighborjoining method. The type strain of Gluconacetobacter liquefaciens was used as an outgroup. The numerals at nodes of the respective branches indicate bootstrap values (\%) derived from replications

\section{CONCLUSION}

The production of DHA by acetic acid bacteria has already been known from early days $[2,4,8]$. The thirty-one DHA-producing AAB obtained in Vietnam were distributed only in the three genera Acetobacter, Gluconobacter and Gluconacetobacter. Especially, the excellent producers of DHA were restricted only to the genus Gluconobacter [2, 3, 6, 10, 13]. The ten isolates assigned to the genus Gluconobacter produced $22.20-25.98 \mathrm{mg} / \mathrm{mL}$ of DHA for the cultivation of two days by shaking at $150 \mathrm{rpm}$. In a certain Thai isolate, the production of DHA achieved in $21 \mathrm{mg} / \mathrm{mL}$ for $48 \mathrm{~h}$ cultivation [9].
These data suggested that the ten Gluconobacter isolates from Vietnam gave a yield of DHA production similar with that of the Thai isolate.

Phylogenetically, the ten isolates that were potential DHA producers were included in the lineage of the genus Gluconobacter. Of the ten, the six isolates, VTH-AE44, VTH-AE83, VTHAH39, VTH-AH59, VTH-AE18 and VTH-AH82 were suggested to be candidates for three new species. The systematic study of the six isolates will be presented elsewhere.

Acknowledgements: The authors express their thanks to Professor Yuzo Yamada, Japan for revising the manuscript.

\section{Trang 36}




\section{Phân lập vi khuẩn acetic acid sản sinh dihydroxy-acetone ở Việt Nam}

- Vũ Thị Lan Hương

- Nguyễn Thị Kim Oanh

- Bùi Thị Thu Vân

- Bùi Thị Tú Uyên

- Ngô Đại Nghiệp

- Đặng Thị Phương Thảo

Trường Đại học Khoa học Tự nhiên, ĐHQG-HCM

- Pattaraporn Yukphan

National Center for Genetic Engineering and Biotechnology (BIOTEC), NSTDA, Thái Lan TÓM TÁ́T

Sáu muooi sáu chủng vi khuẩn acetic acid đã được phân lập tù 45 mẫu hoa, quả thu thập tại TP. Hồ Chí Minh, Việt Nam. Trong đó, 31 chủng được xác định là vi khuẩn acetic acid có thể sản sinh dihydroxyacetone dự vào phản úng vói thuốc thư Fehling và được phân chia thành 3 nhóm theo đặc điểm kiểu hình. Nhóm I gồm 14 chủng đuoọc xác định thuộc chi Acetobacter. Nhóm II gồm 13 chủng được xác định thuộc chi Gluconobacter. Nhóm III gồm 4 chủng còn lại thuộc chi Gluconacetobacter. Trong 13 chủng

thuộc nhóm II, có muời chủng sản sinh luợng DHA nhiều hơn luợng DHA thu thận được tù̀ chủng Gluconobacter oxydans NBRC $14819^{T}$ $(22,2-26,0 \mathrm{mg} / \mathrm{mL}$ so vói $19,8 \mathrm{mg} / \mathrm{mL})$. Mưòi chủng này đuoọc đánh giá có khả năng ứng dụng trong sản xuất DHA. Phân tích mối quan hệ phát sinh loài dựa trên vùng trình tư gene mã hóa $16 S$ rRNA cho thấy có 6 trong 10 chủng vi khuẩn tiềm năng ứng dụng trong sản xuất DHA có khả năng là nhũng đơn vị phân loại mói trong chi Gluconobacter.

Tù khóa: vi khuẩn acetic acid, sinh dihydroxyacetone, Gluconobacter

\section{REFERENCES}

[1]. T. Asai, Acetic acid bacteria: Classification and biochemical activities. University of Tokyo Press, Tokyo. Acetic acid bacteria: Classification and biochemical activities, University Tokyo Press, Tokyo (1968).

[2]. T. Asai, H. Iizuka, K. Komagata, The flagellation and taxonomy of genera Gluconobacter and Acetobacter with reference to the existence of intermediate strains, J. Gen. Appl. Microbiol., 10, 95-126 (1964).

[3]. R.L. Burner, Determination of reducing sugar value 3,5-dinitrosalicylic acid method, Method in Carbohydr. Chem., 4, 67-71 (1964).
[4]. V.H. Cheldelin, Metabolic pathways in microorganisms, John Willey \& Sons, Inc., New York (1961).

[5]. J. Felsenstein, Confidence limits on phylogenies: An approach using the bootstrap, Evol., 39, 783-791 (1985).

[6]. A. Gupta, V.K. Singh, G.N. Qazi, A. Kumar, Gluconobacter oxydans: its biotechnological applications, J. Mol. Microbiol. Biotechnol., 3, 445-456 (2001).

[7]. M. Kimura, A simple method for estimating evolutionary rates of base substitutions through comparative studies of nucleotide sequences, J. Mol. Evol., 16, 111-120 (1980).

[8]. K. Komagata, T. Iino, Y. Yamada, The family Acetobacteraceae In: Rosenberg E, 
DeLong EF, Lory S, Stackebrandt E, Thompson F ( $4^{\text {th }}$ ed) The Prokaryotes: Alphaproteobacteria and Betaproteobacteria, Springer, New York, 4, 6, 3-78, (2014).

[9]. J. Kommanee, S. Tanasupawat, P. Yukphan, D. Moonmangmee, N. Thongchul, Y. Yamada, Identification and oxidation products of Gluconobacter strains isolated from fruits and flowers in Thailand, Int. J. Biol, 4, 69-80 (2012).

[10]. S.R. Lidia, B. Stanislaw, Production of dihydroxyacetone from an aqueous solution of glycerol in the reaction catalyzed by an immobilized cell preparation of acetic acid bacteria Gluconobacter oxydans ATCC 621, Eur. Food. Res. Technol., 235, 1125-1132 (2012).

[11]. A. Moryadee, W. Pathum-Aree, Isolation of thermotolerant acetic acid bacteria from fruits for vinegar production, Res. J. Microbiol., 3, 209-2012 (2008).

[12]. Y. Muramatsu, P. Yukphan, M. Takahashi, M. Kaneyasu, T. Malimas, W. Potacharoen, Y. Yamada, Y. Nakagawa, M. Tanticharoen, K. Suzuki, 16S rRNA gene sequences analysis of acetic acid bacteria isolated from Thailand, Microbiol. Cult. Coll., 25, 13-20 (2009).

[13]. N. Saichana, K. Matsushita, O. Adachi, I. Fréborta, J. Frébortová, Acetic acid bacteria: A group of bacteria with versatile biotechnological applications, Biotech. Adv., 1260-1271 (2015).

[14]. N. Saitou, M. Nei, The neighbor-joining method: A new method for reconstructing phylogenetic trees, Mol. Biol. Evol., 4, 406425 (1987).

[15]. M. Takahashi, P. Yukphan, Y. Yamada, K. Suzuki, T. Sakane, Y. Nakagawa, Intrageneric structure of the genus Gluconobacter analyzed by the 16S rRNA gene and 16S-23S rRNA gene internal transcribed spacer sequences, J. Gen. Appl. Microbiol., 52, 187-193 (2006).
[16]. K. Tamura, D. Peterson, N. Peterson, G. Stecher, M. Nei, S. Kumar, MEGA 5: Molecular evolutionary genetics analysis using maximum likelyhood, evolutionary distance, and maximum parsimony methods, Mol. Biol. Evol., 28, 2731-2739 (2011).

[17]. J.D. Thompson, T.J. Gibson, F. Plewniak, F. Jeanmougin, D.G. Higgins, The CLUSTAL $\mathrm{X}$ windows interface: Flexible strategies for multiple sequence alignment aided by quality analysis tools, Nucleic Acids Res., 25, 48764882 (1997).

[18]. H.T.L. Vu, P. Yukphan, W. Chaipitakchonlatarn, T. Malimas, Y. Muramatasu, U.T.T. Bui, S. Tanasupawat, K.C. Duong, Y. Nakagawa, H.T. Pham, Y. Yamada, Nguyenibacter vanlangensis gen. nov., sp. nov., an unusual acetic acid bacterium in the $\alpha$-proteobacteria, J. Gen. Appl. Microbiol., 59, 153-166 (2013).

[19]. Y. Yamada, Y. Okada, K. Kondo, Isolation and characterization of "polarly flagellated intermediate strains" in acetic acid bacteria, J. Gen. Appl. Microbiol., 22, 237-245 (1976).

[20]. Y. Yamada, R. Hosono, P. Lisdiyanti, Y. Widyastuti, S. Saono, T. Uchimura, K. Komagata, Identification of acetic acid bacteria isolated from Indonesian sources, especially of isolates classified in the genus Gluconobacter, J. Gen. Appl. Microbiol., 45, 23-28 (1999).

[21]. Y. Yamada, P. Yukphan, Genera and species in acetic acid bacteria, Int. J. Food Microbiol., 125, 15-24 (2008).

[22]. P. Yukphan, W. Potacharoen, S. Tanasupawat, M. Tanticharoen, Y. Yamada, Asaia krungthepensis sp. nov., an acetic acid bacterium in the $\alpha$-proteobacteria, Int. J. Syst. Evol. Microbiol., 54, 313-316 (2004).

[23]. P. Yukphan, T. Malimas, W. Potacharoen, S. Tanasupawat, M. Tanticharoen, Y. Yamada, Neoasia chiangmaiensis gen. nov., sp. nov., a novel osmotolerant acetic acid bacterium in the $\alpha$-proteobacteria, J. Gen. Appl. Microbiol., 51, 301-311 (2005).

\section{Trang 38}

